\title{
A new tool for the remote sensing of groundwater tables: satellite images of pastoral wells
}

\author{
Bernard Collignon(1)
}

\begin{abstract}
In the Sahara and the Sahel, groundwater is a limited and indispensable resource for pastoral livestock farming. The daily life and work of the herders are organised around the location of the wells and the depth of the water table. To ensure the sustainable development of these regions, it is therefore essential to develop accurate piezometric maps, even in the areas that are most difficult to access.

Thanks to high-resolution satellite images, the tracks made by cattle, goats and camels in the Sahara and Sahel could become a key indicator of the depth of the water table.

In the northern Sahel, pastoralists water their livestock from deep wells. To draw water, they hitch oxen or camels to a rope whose length is an accurate measure of the depth of the piezometric surface of the water table. When pulling on this rope, the animals leave deep tracks on the ground that can be observed and measured on satellite images.

We have developed a remote sensing technique that allows us to (a) identify pastoral wells, (b) isolate the tracks left by the animals used to draw water, and (c) use these animal tracks to estimate the water depth.

After carefully calibrating the method, we were able to use open data (Landsat) and satellites images freely accessible data thanks to Google Earth Pro (SPOT and Worldview) to draw up, in just a few weeks, the piezometric map of a large aquifer $\left(200,000 \mathrm{~km}^{2}\right)$ that is not easily accessible by other means due to the prevailing insecurity that has persisted in this part of the Sahel region for several years. This same method was then subsequently tested and validated on two other aquifers, one in Nigeria and one in Niger.
\end{abstract}

Keywords: Pastoral wells - remote sensing - piezometric surface - water table - Batha, Chad

\section{Introduction}

Since 2015, we have supervised two major European Union-funded drilling programmes in the northern part of the Chadian Sahel: the project PAEPA (Programme d'Eau Potable et d'Assainissement - 1100 boreholes, including 264 in the study area) and the project RESTE (Résilience et Emploi au Lac Tchad - 200 boreholes in the study area). These boreholes have enabled us to greatly improve our knowledge of the Plio-Quaternary aquifer in the Chadian Sahel.

Correspondence: collignon@hydroconseil.com

HYDROCONSEIL, 198, chemin d'Avignon, 84470 Chateauneuf de Gadagne, France
However, we still lack water level measurements for the pastoral areas on the northern fringe of the aquifer as the drinking water drilling campaigns have focused on the most densely populated central and southern parts of the region (Fig. 1 - map of PAEPA and RESTE drilling programmes, as compared to the study area).

Drilling campaigns have not explored the northern parts of the basin despite a large proportion of overall groundwater abstraction taking place in this area. This is justified by the fact that tube wells do not meet herders' needs. Instead, they require deep, large-diameter wells dug in the sands, i.e. wells for which traditional welldiggers (who work in the informal sector and are only
Springer Open

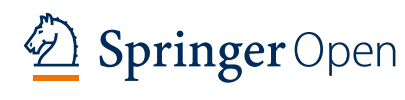

(c) The Author(s). 2020 Open Access This article is licensed under a Creative Commons Attribution 4.0 International License, which permits use, sharing, adaptation, distribution and reproduction in any medium or format, as long as you give appropriate credit to the original author(s) and the source, provide a link to the Creative Commons licence, and indicate if changes were made. The images or other third party material in this article are included in the article's Creative Commons licence, unless indicated otherwise in a credit line to the material. If material is not included in the article's Creative Commons licence and your intended use is not permitted by statutory regulation or exceeds the permitted use, you will need to obtain permission directly from the copyright holder. To view a copy of this licence, visit http://creativecommons.org/licenses/by/4.0/. 


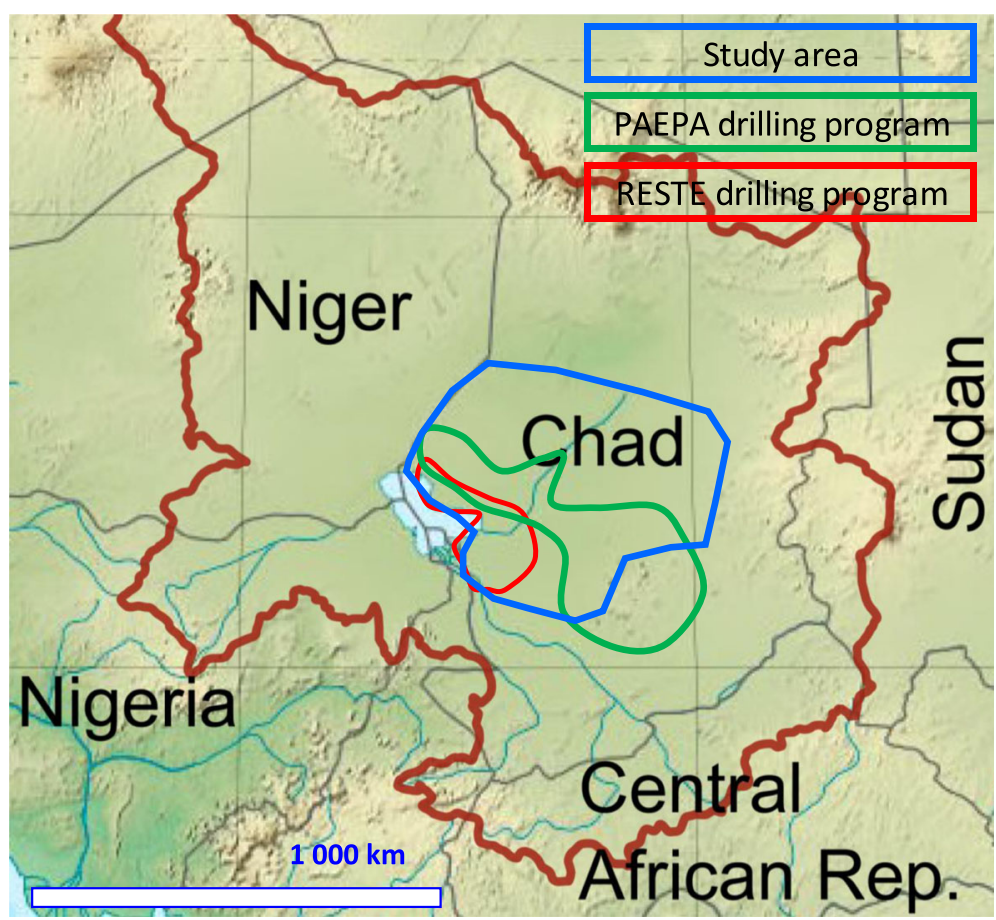

Fig. 1 Location of the study area (outlined in blue), in the centre of the Lake Chad basin (brown line). Map source: mons. wikimedia.org/w/index.php?curid $=25924986$

part registered in government databases) are more efficient than formal enterprises [3].

It is particularly difficult and costly to carry out measurement campaigns in these areas because they are remote, the trails through sand dunes are difficult to follow and some areas (Kanem, Lake) are extremely insecure because of Boko Haram attacks.

This lack of data raises difficulties for sustainable groundwater management because it is impossible to establish the water balance of the aquifer and assess its recharge without a good piezometric map. This information is vital for guiding regional development strategies and answering the fundamental question of whether there is sufficient groundwater available to accompany the anticipated increase in abstraction generated by the growth of the population and livestock.

The objective of this research is therefore to establish the piezometric map of Batha, Kanem and Bahr el Ghazal $\left(200,000 \mathrm{~km}^{2}\right)$ by using existing satellite images to supplement traditional water levelling.

In order to establish the piezometric map of such a vast area, where logistics are so difficult, it was desirable to use satellite data, as well as open-access data, because we did not have the budget to acquire coverage of such a vast area by a commercial satellite.

Images produced by Landsat satellites are available free of charge and have already been successfully used to study the coverage of natural or cultivated environments, such as burnt areas [1, 2], eroded areas [18], saline soils [9] or wetlands [12]. The exploitation of these images is then based on the development of algorithms that automatically classify groups of pixels according to their reflectance properties in different wavelengths [4].

We have sought to use this type of image to locate and study pastoral wells. The weak point of Landsat images is their low resolution: $30 \mathrm{~m}$ in the best case. This only allows for the identification of large artifacts, such as plot boundaries differentiated by vegetation cover [5, 15]. Nevertheless, this resolution is not sufficient to identify and measure smaller artifacts, such as pastoral wells.

With a diameter of $3 \mathrm{~m}$, these objects are too small to be identified directly on most satellite images. Landsat resolution is $30 \mathrm{~m}$ at best and that of SPOT is $2 \mathrm{~m}$ at best. In practice, a well is not directly visible in a Landsat image and is very difficult to discern in a SPOT image. However, these structures can be spotted, due to the changes they cause in their environment, over a radius that varies from $100 \mathrm{~m}$ to several kilometres. In addition, very high-resolution images captured by the Worldview, Sentinel, Pleiades or Gaofen satellites allow even more detailed analysis of the artifacts, as has become common practice in urban planning [19].

We did not have the budget to acquire the coverage of a $200,000 \mathrm{~km} 2$ area by a commercial satellite and tried to exploit the library of freely accessible data through Google Earth Pro. 


\section{Context}

This region is in the northern half of the Chadian Sahel and it is extremely arid. Annual rainfall is limited 100 to $300 \mathrm{~mm}$ per year, with strong inter-annual variations. Agriculture is limited to a few flood recession crops grown in the inter-dune depressions. However, the region is relatively densely populated with 2 million inhabitants on a $200,000 \mathrm{~km}^{2}$ area as a whole. Population includes different groups of nomadic pastoralists (Arabs, Tedas, Dazas, Boudoumas, Mbororos, etc.) who have developed a way of life and farming that is well-suited to this specific eco-system. They derive their livelihoods from transhumant ruminant breeding in order to maximise the use of the temporally and spatially highly variable fodder resources [6].

There is an enormous amount of livestock in this region. The inventory published by the Ministère de l'Elevage (2016) lists 32 million head of ruminants in the five regions of Chad alone (Table 1). In these areas, the water demand of livestock is thus higher than the demand for drinking water.

The sustainability of this production model relies on the use of hundreds of wells, which are scattered throughout the grazing areas in order to avoid overly high concentrations of livestock degrading fodder reserves through overgrazing around water points [7, 16]. A few motorised boreholes have been installed by the government in the last 20 years but, as they are relatively few in number, these are only used to supplement the wells (we have identified fewer than 20 that are functional) and their high individual production leads to local overgrazing.

\section{Pastoral wells}

In the Sahel and the Sahara, the depth of the wells used for livestock varies greatly depending on the local topography and hydrogeological conditions. The shallower wells are simple sumps a few metres deep, which are dug in flood-prone shallows and rebuilt after each rainy season. The deeper wells are impressive structures of sometimes more than $100 \mathrm{~m}$

Table 1 Livestock numbers in the study area (in thousands of head) [10]

\begin{tabular}{lllllll}
\hline & Cattle & Sheep & Goats & Camels & Horses & Donkeys \\
\hline Batha & 4269 & 3274 & 3000 & 913 & 114 & 228 \\
Kanem & 1745 & 1988 & 2108 & 468 & 100 & 245 \\
Bahr el Gazal & 747 & 720 & 815 & 290 & 47 & 126 \\
Lac & 2080 & 980 & 3039 & 102 & 60 & 242 \\
Hadjer Lamis & 1841 & 1178 & 1543 & 57 & 73 & 133 \\
& $\mathbf{1 0 , 6 8 2}$ & $\mathbf{8 1 4 0}$ & $\mathbf{1 0 , 5 0 5}$ & $\mathbf{1 8 3 0}$ & $\mathbf{3 9 4}$ & $\mathbf{9 7 4}$
\end{tabular}

Source: Chad - General Livestock Census- RGE 2012/2015 deep. These are the wells for which satellite images will be used to measure the depth of the water table.

Most of these deep wells are dug in the loose sedimentary formations (sands) of the Pliocene and Quaternary periods. They are dug by hand by well-digging contractors, who are paid by the villagers and herders. The well casing is braced in wood (traditional wells) or reinforced concrete (modern wells). In both cases, the depth of water at the bottom of the well is limited to a few metres due to the difficulties of digging in unstable sand formations [3].

\section{Water abstraction in the Sahara and the Sahel}

In the saharian and sahelian regions of Chad, only a small minority of pastoral wells are motorised. For more than $95 \%$ of the wells, water is extracted by the herders themselves, using cattle in the southern zone and horses and donkeys and, in rare cases, camels in the northern zone. Water is drawn from the well by hitching one or two animals to a long rope, the other end of which is attached to a 50 to 801 leather sack. The rope passes over a wooden pulley, placed vertically over the well. This pulley is hung either on a metal gantry for modern wells with cement casing or on a wooden fork for traditional wells braced with branches. All the farmers that come to withdraw water harness one or more of their animals to a rope whose length is equal to the depth of the piezometric surface [3] (Fig. 2).

\section{A new methodology for establishing piezometric maps Locating pastoral wells on satellite images}

Pastoral wells can be identified on satellite images by the tracks left by the herds that converge on the wells. These tracks usually radiate towards the wells (Fig. 3), as the herds are free grazing on unfenced land. The tracks leading to the most frequented wells

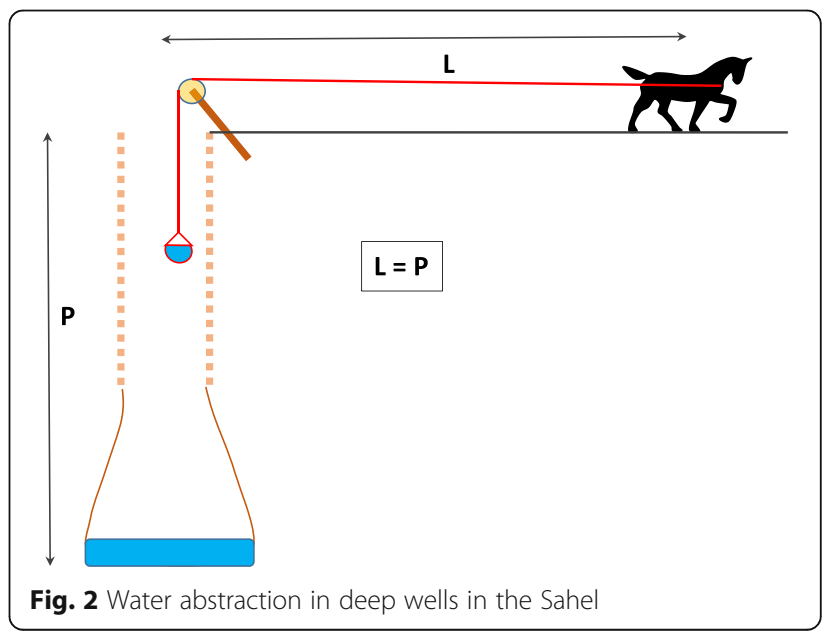



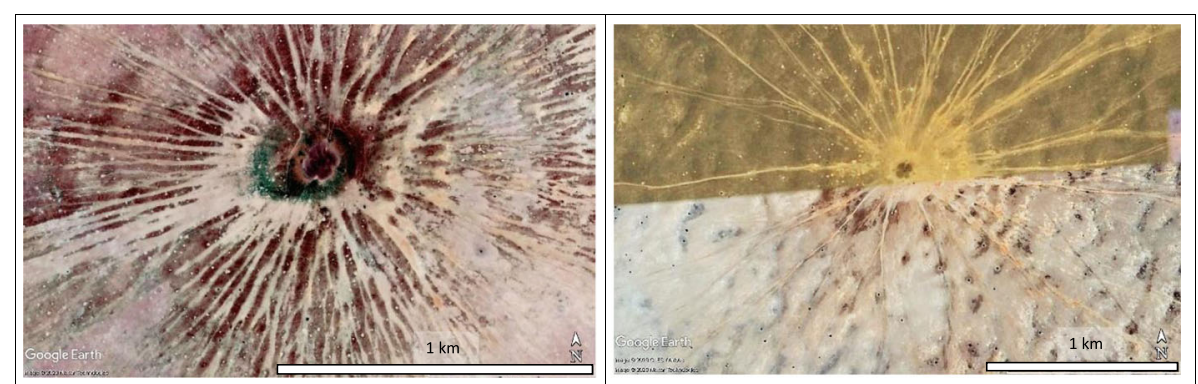

Fig. 3 Using livestock tracks to locate pastoral wells

extend over a radius of more than one kilometre and are marked by clear bands a few tens of metres wide. They correspond to the high reflectance of the sandy soil that has been turned over by the herd and eroded by the wind.

\section{Spectral signature of ruminant dung}

In the centre of the radiating tracks, a dark area, 40 to $150 \mathrm{~m}$ in diameter, can very often be seen on the satellite images. This dark area is created by the accumulation of dung from ruminants waiting around the well before going to drink. The areas around the wells are thus places where the organic matter produced by the herds is concentrated [6]. The excreta, mixed with sand, forms thick layers (sometimes more than a meter thick). The spectral signature of this organic matter-rich layer is extremely strong: it has a very low reflectance in both the visible and near infrared spectra [4].

These dark patches of organic matter are a highly reliable signature of pastoral wells, as they endure from one year to the next, even during months when there are no cattle, and can remain visible for several years (Fig. 4).

Areas of accumulated organic matter often have a characteristic four-leaf clover shape (Fig. 5). This shape reflects the most common geometry of the intake structures, which have 4 pulleys arranged at right angles.

There is also a minority of wells, especially the deepest wells that have 5 or 6 forks created as a result of herders trying to compensate for the long drawing time (i.e. the long trek of the draught animal) by increasing the number of animals that can draw water simultaneously.

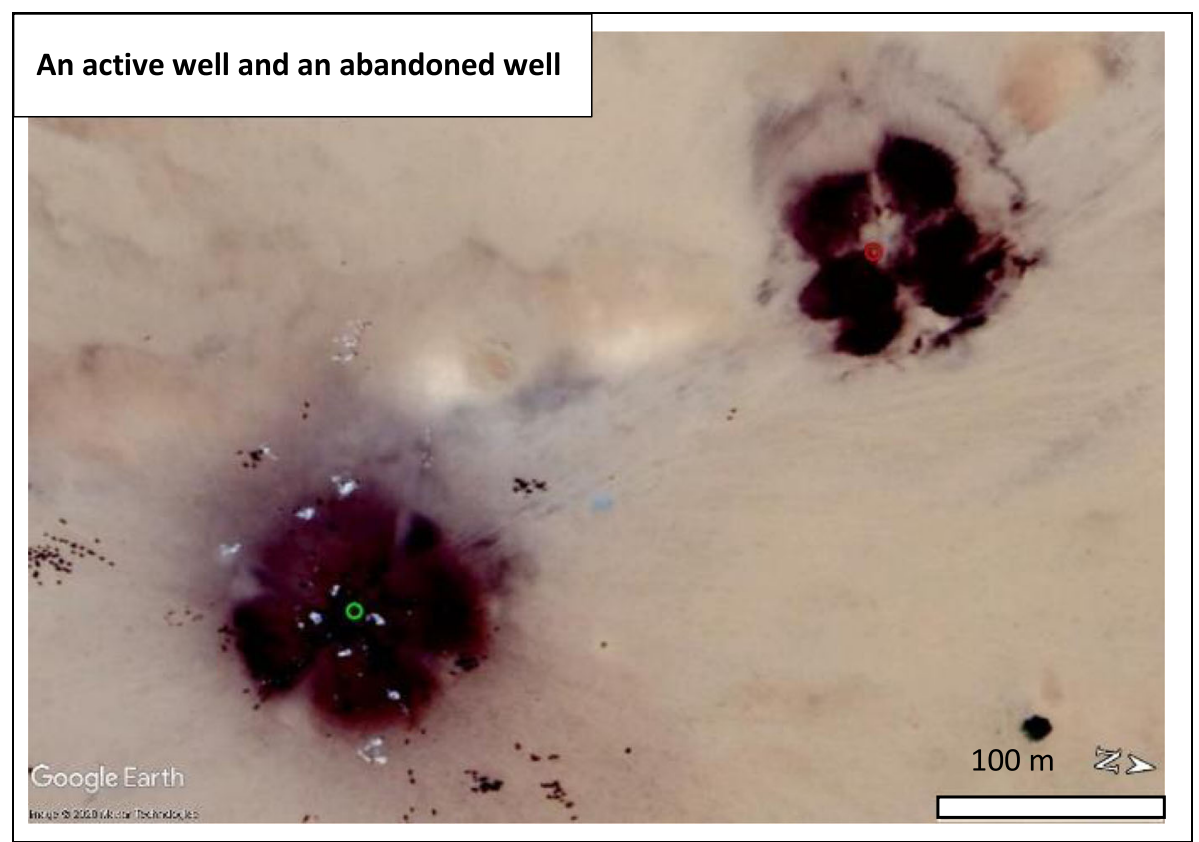

Fig. 4 Satellite image of an active well with cattle (bottom) and the old well it replaced (top) 

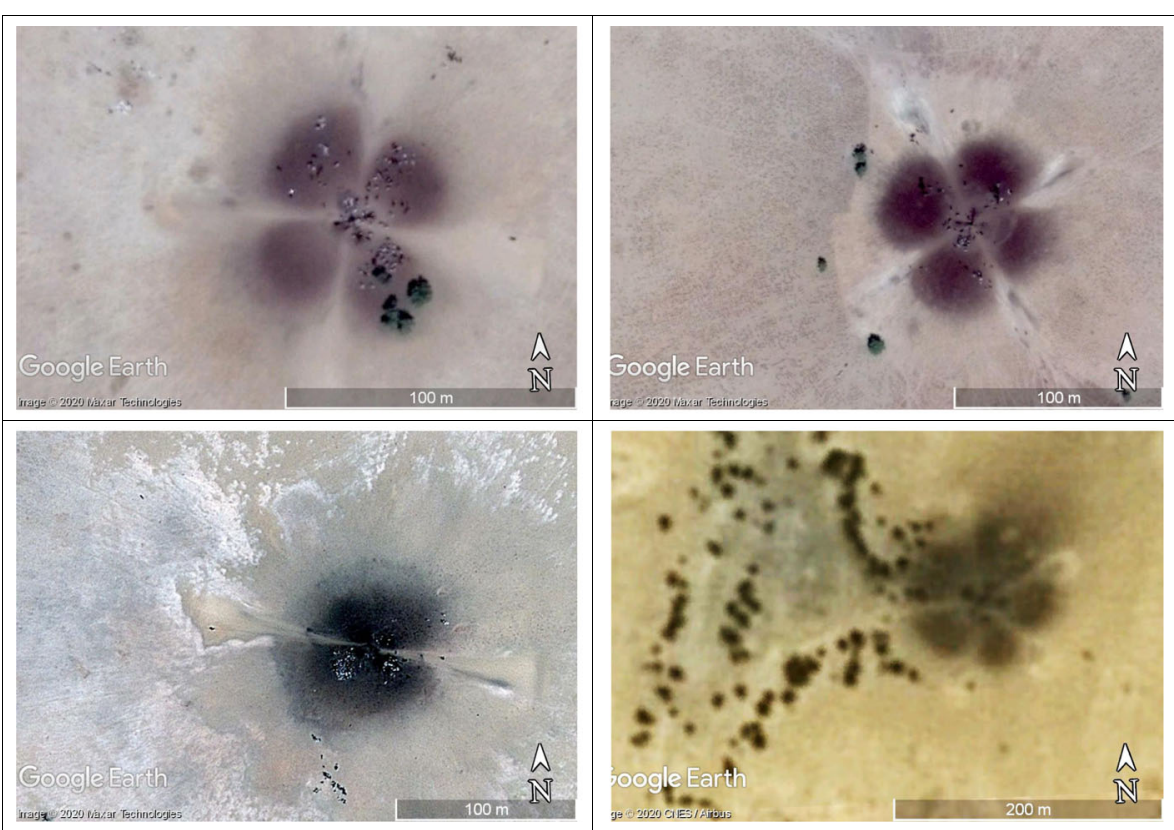

Fig. 5 Typical satellite imagery of pastoral wells in Batha and Bahr el Ghazal. Top: very high resolution (Worldview) images of 4-pulley wells. Bottom left: very high resolution image of a 2 pulley shaft. Bottom right: high resolution (SPOT) image of a 5 pulley well

\section{Identifying the water withdrawal tracks of draught animals} on satellite images

The draught animals follow a very regular, welldefined route, which is shaped like a flower petal (Fig. 5 and Fig. 6). They start by moving away from the well in a straight line until the leather sack reaches the surface. The shepherd then unties the rope, and the animal charts a semi-circular course of a few metre radius before returning to the well in a straight line. Along this track, the sand, which is regularly churned up by the animals, is weakened and eroded by the wind and its reflectance is high.

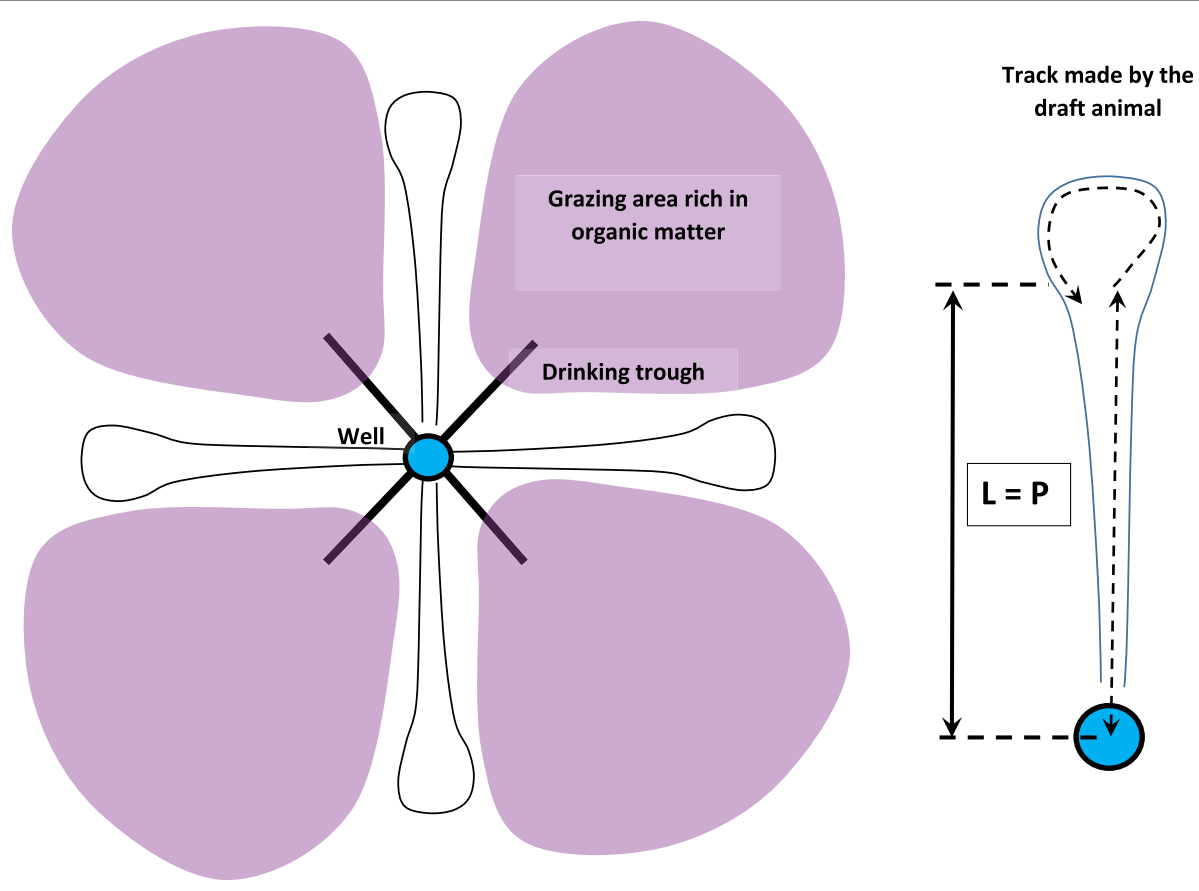

Fig. 6 Interpreting the satellite images 
A series of similar tracks can be observed around each well. The number of tracks ranges from 1 to 8 , depending on the number of shepherds using the well. The most common number being 4, which corresponds to 4 pulleys arranged at right angles. Between these cattle tracks is a dark area corresponding to the grazing area of the animals waiting their turn to approach the watering troughs next to the well (Fig. 6).

Locating pastoral wells on satellite images is a delicate operation, which is best carried out using highresolution images (e.g. those collected by SPOT, Worldview, Pleiades, KOMPSAT satellites, etc.). With some practice, it is possible to locate wells using low resolution images (LANDSAT type) but these cannot be used to measure cattle tracks (Table 2).

In order to be able to apply this method on the scale of large aquifers (several dozen thousand $\mathrm{km}^{2}$ ), it is essential to be able to use open access highresolution satellite images. Landsat images are available free of charge, but as we have seen above, their resolution is not sufficient to identify and measure the length of tracks left by draught animals. For this reason, we used commercial satellite images (SPOT and Worldview) available for free on the Google Earth Pro platform. This platform offers two advantages: its ease of access and the possibility of consulting several successive images of the same area (an important advantage in the event of cloud cover on one of the images). The disadvantage of this platform is the heterogeneity of the images accessible online. Some zones are less well covered than others and the robustness of the piezometric information is then downgraded (this is the case, for example, of the zone located on the Chad-Niger border, north of the 15th parallel).

As part of the Plio-Quaternary aquifer study, we systematically searched for pastoral wells on images collected via Google Earth Pro ${ }^{\circ}$. Within just a few days, we located more than 620 wells in the study area alone (Kanem, Bahr el Ghazal, Hadjer Lamis, Lac and Batha). This represents more than half of the pastoral wells that were inventoried 6 years ago [8]. Analysis of satellite images is thus an effective tool for identifying pastoral wells in areas of the Sahel region.
We systematically looked for traces of tracks made by animals used to withdraw water from these wells and, in the majority of cases, we were able to identify and measure them $(65 \%$ of the wells located, i.e. 420 measurements).

This work was carried out by direct image analysis, which is somewhat time-consuming. Therefore, it would obviously be useful to automate this search and measurement procedure. However, this could prove difficult because the intensity of the markers varies largely depending on the soil (clay or sand), the season (dry or wet) and even the time of the satellite's passage. Moreover, the different pastoral well markers on the images do not last for the same duration:

- the organic matter-enriched zone is a strong marker and deposits are still visible for several years after the well has been abandoned (Fig. 2);

- the paths radiating towards the well are also a strong marker, remaining visible for a few years;

- the tracks made by the draught animals are more fragile markers, which disappear after a few months if the well is abandoned or if the area is cultivated.

\section{Which satellite images should be used?}

This work was carried out using images available in the public domain and compiled in Google Earth Pro ${ }^{\circ}$. The source images vary according to the area and this allows us to compare the performance of the method for different image resolutions (Table 2).

The low resolution images $(30 \mathrm{~m}-$ Landsat 7 and 8 satellites) are useful for quickly locating some of the wells over very large areas. However, these images cannot be used to discern the tracks made by draught animals or to assess the depth of the piezometric surface.

Thus, high-resolution images are required for this (2 $\mathrm{m}$ such as SPOT 6 and 7 satellites) and, if possible, very-high resolution satellites $(<1 \mathrm{~m}$ such as Worldview 3 and 4, Sentinel, Gaofen, etc.). These images allow to measure the length of the tracks made by draught animals and determine the depth of the piezometric surface. The length to be measured is the distance from the centre of the well, where the

Table 2 Potential of the method per type of image resolution

\begin{tabular}{|c|c|c|c|c|}
\hline & Resolution & Radiant Tracks & Ring of Organic Matter & Cattle Tracks \\
\hline Landsat 7 and 8 & $30 \mathrm{~m}$ & $\begin{array}{l}\text { Often discernible on busy } \\
\text { wells }\end{array}$ & Discernible, but not measurable & Never visible \\
\hline SPOT 6 and 7 & $2 \mathrm{~m}$ & Always discernible & $\begin{array}{l}\text { Often clearly visible and } \\
\text { measurable }\end{array}$ & Often visible and sometimes measurable \\
\hline $\begin{array}{l}\text { Worldview } 3 \\
\text { and } 4\end{array}$ & $0.3 \mathrm{~m}$ & Always discernible & $\begin{array}{l}\text { Always clearly visible and } \\
\text { measurable }\end{array}$ & $\begin{array}{l}\text { Always visible and measurable; cattle are often even } \\
\text { countable }\end{array}$ \\
\hline
\end{tabular}


different cattle paths meet, to the point where the animal starts to turn when it has been released from its load (Fig. 6).

\section{Calibration of the method (field test)}

To validate an investigation method based on satellite images, it is essential to compare the values estimated in this way with values measured directly in the field, which will serve both as a test of the method and as a standard [4].

To measure the depth of the piezometric surface, a simple and reliable method is used whereby the depth is measured directly from inside a well or borehole at rest (without pumping). In pastoral areas, however, this method is complicated by two factors: (a) a large number of pastoral wells are located in depressions in the middle of dune fields unsuitable for motor vehicles; and (b) in order to measure the level, water withdrawal must be stopped for at least one hour, which is difficult in a region where the demand for water is so high.

We were nevertheless able to calibrate the method by combining the analysis of satellite images with direct water level measurements taken from new boreholes located close by the dug wells, before the pumps were installed. Figure 7 shows that the two methods give comparable depths, with a root mean square deviation of less than $5 \mathrm{~m}$, which is acceptable. The correlation between the two types of measurements is excellent. Satellite images of draught animal tracks are therefore a reliable indicator of the depth of the piezometric surface.

\section{Piezometric remote sensing mapping}

The basic tool used to define groundwater flow in an aquifer is the piezometric map, i.e. the map of the elevation of the free surface of the water in wells left at rest.

We have constructed the piezometric map below (Fig. 8 - top) using water level measurements taken in 264 boreholes (installed through the PAEPA and RESTE drilling programme). This data is robust as it is taken from similar drilling programmes that were completed over few years and supervised by the same team of hydrogeologists (measurement and reporting methods are therefore consistent).

This map as well as those in Fig. 9 was built using the Surfer software which allows to choose many options for data interpolation (inverse distance, natural neighbour, kriging...). Block kriging gave the most satisfactory results. As a precaution, extrapolation was deliberately limited to the polygon surrounding all the measurement points, as the objective of these maps is to provide hydrogeologists with sufficiently robust

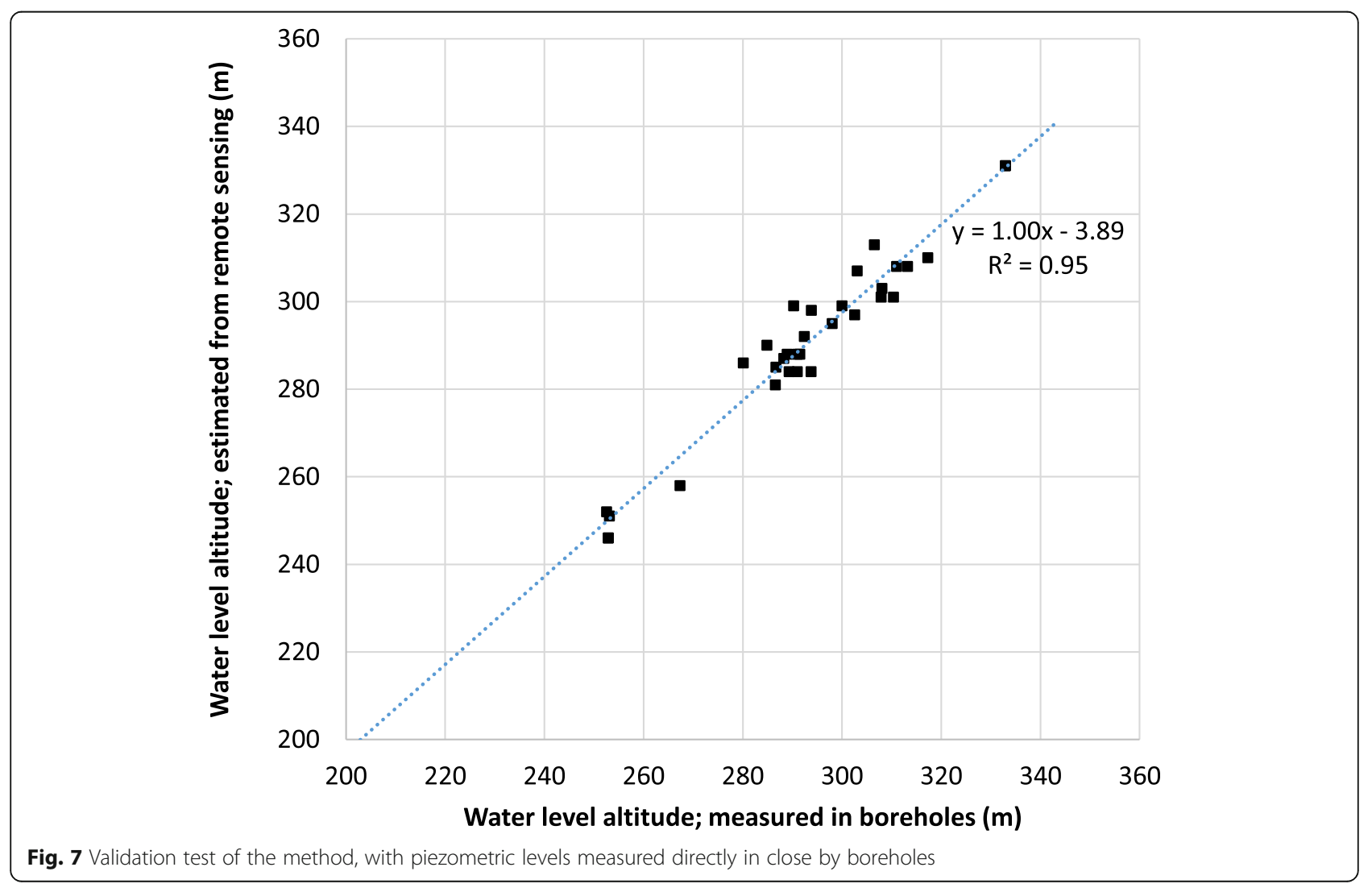




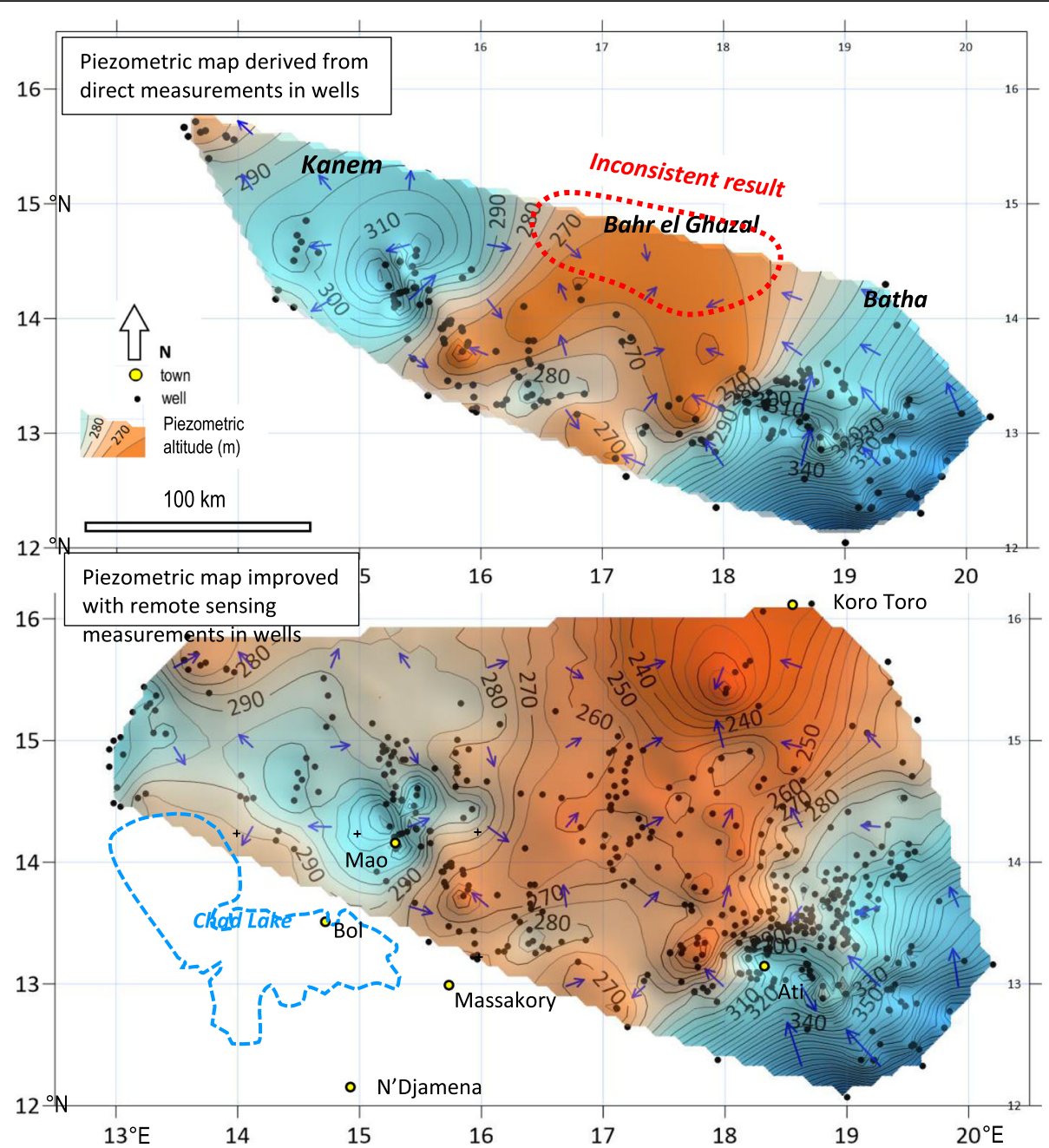

Fig. 8 Piezometric map of Northern Chad: based on water level measurements in PAEPA boreholes (top) and after the addition of remote sensing information (bottom)

information to be able to programme future drilling work.

The map provides a realistic picture of the piezometric surface and groundwater flows south of $14^{\circ} \mathrm{N}$. However, it does have one weakness as $90 \%$ of the measurement points are located in the southernmost $20 \%$ of the aquifer, where the vast majority of the sedentary housing is located. Unfortunately, there are very few measuring points in the areas north of $14^{\circ} \mathrm{N}$, despite these being important water abstraction areas as they are the main winter grazing areas. In the absence of direct measurements, the piezometric map in this area has been drawn by interpolation between widely spaced measurement points.

This piezometric map (Fig. 8 top) shows the behaviour of the aquifer in two of its main recharge areas: the Kanem dunes (to the west) and the Guera foothills (to the east). However, it is not consistent with previously recognised behaviour in the Barh el Ghazal paleo-valley. This map suggests that the flow runs from north to south (Fig. 8 - red zone), whereas other surveys have shown that, in this area, underground flows run northwards towards the Bodele depression $[11,13,14,17]$.

This anomaly is a result of data processing under Surfer ${ }^{\oplus}$, as there is limited data available for this area, which is located between two other areas where much more data have been collected (Fig. 8 - black dots). In order to obtain a better piezometric map, more measuring points need to be put in place in Bahr el Ghazal, north of the 14th parallel, i.e. in the area where village boreholes are rare.

However, this is precisely the area with the highest number of pastoral wells, and where we have been able to successfully apply the method by interpreting satellite images of draught animal tracks. The second 


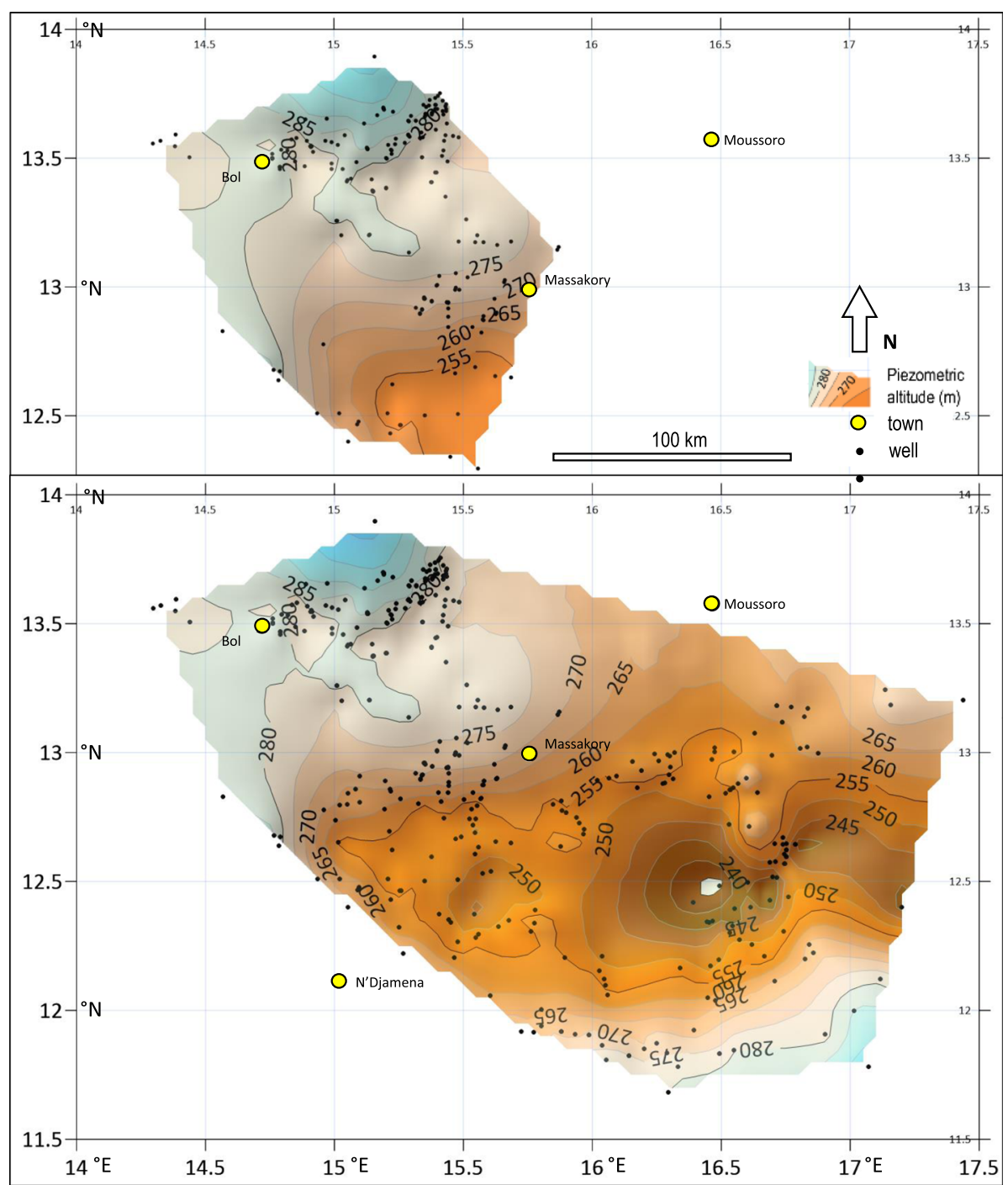

Fig. 9 Piezometric maps of the Lac and Hadjer Lamis regions: (a) based on direct measurements in boreholes (top) and (b) combined with additional information from pastoral wells (bottom)

piezometric map (Fig. 8 bottom) was thus constructed by simultaneously using measurements from the same 264 boreholes and the measurement of draught animal tracks around 500 pastoral wells, the vast majority of which are located north of the 14th parallel. This map is much more complete, more accurate and more detailed than not only the previous map but also most of the other piezometric maps previously developed for the region.

The next map, Fig. 9, shows the same method being applied in the area directly to the East of Lake Chad. The 200 boreholes drilled as part of the RESTE programme provide a sound basis from which to draw an accurate piezometric map of the Plio-Quaternary aquifer around Lake Chad and in the western half of the Hadjer Lamis region (top).
However, there were no boreholes drilled in the eastern part of Hadjer Lamis, where a piezometric depression had already been reported [14]. To confirm the extent and depth of this depression, we looked for pastoral wells on satellite images and applied the method described above. The result was a piezometric map extending to $17^{\circ} \mathrm{E}$ longitude. On the bottom of Fig. 9, the extended map can be seen to be in perfect continuity with the map established solely on the basis of water level measurements in boreholes.

\section{Method limits and uncertainties}

In arid or semi-arid regions, this method is applicable wherever animals are commonly used to withdraw 
water, i.e. where the water depth is greater than $20 \mathrm{~m}$. When the water level is not very deep, shepherds prefer to draw water by hand.

The length of the tracks observed on the satellite images equates to the weighted average of many tracks and thus covers different water table situations that cannot be measured during a single piezometric campaign, in particular the difference in levels between the morning (high) and the evening (low).

However, this measurement only pertains to the water table level during the grazing season (July to January) and not the level during the dry season, when the herds have migrated south (Guera, Southern Hadjer Lamis, Salamat). This method is therefore not suitable for monitoring seasonal groundwater level changes.

\section{Potential for replication}

The example of the Lake Chad basin demonstrates that it is possible to construct piezometric maps by remote sensing in pastoral livestock areas wherever animals are predominantly used to withdraw water. It obviously assumes that there are large herds producing high volumes of organic matter that will make it possible to locate wells due to the low reflectance of organic matter in the light spectrum.

As far as we know, this method had never been used to establish regional piezometric maps. It does not replace direct water level measurements in the field, but it does make it possible to significantly extend map coverage in the Sahel and Sahara areas where the cost of field measurement campaigns is very high (due to logistical constraints) and where access to large swathes of pastoral areas has become almost impossible over the past 5 years due to insecurity.

Remote sensing in arid regions makes it possible to establish in a few weeks a small-scale piezometric map covering areas of several hundred thousand $\mathrm{km} 2$. It requires access to high-resolution satellite images. We have verified that even limited open access to commercial imagery can greatly facilitate the application of the method almost everywhere in the Sahel and the Sahara.

\section{Abbreviations}

PAEPA: Programme d'Eau Potable et d'Assainissement; RESTE: Résilience et Emploi au Lac Tchad

\section{Acknowledgements}

I thank very much Nicola Brodick for an efficient English editing.
Funding

There are no sources of funding for this research.

Availability of data and materials

The original datasets have been included as an additional supporting file.

Consent for publication

Not applicable.

\section{Competing interests}

No financial and non-financial competing interests has been identified.

Received: 9 July 2020 Accepted: 9 September 2020

Published online: 30 September 2020

References

1. Alexandris N, Gupta S, Koutsias N. Remote sensing of burned areas via PCA, Part 1; centering, scaling and EVD vs SVD. Open Geospatial Data, Software \& Standards. 2017;2:17. https://doi.org/10.1186/s40965-017-0028-1.

2. Alexandris N, Koutsias N, Gupta S. Remote sensing of burned areas via PCA, Part 2: SVD-based PCA using MODIS and Landsat data. Open Geospatial Data, Software \& Standards. 2:21, 2017. https://doi.org/10.1186/s40965-0170029-0.

3. Debris T, Collignon B. Entrepreneurs puisatiers du Sahel. Paris: Association Française des Volontaires du Progrès, Ministère de la Coopération; 1994.

4. Girard C-M, Girard M-C. Traitement des données de télédétection. 2ème ed. Paris, Dunod; 1999.

5. Desjardins R, Cavayas F. Possibilités et limites des images satellites TM Landsat en matière d'occupation du sol. Cahier de géographie du Québec. 1991;35:14.

6. Hiernaux P, Diawara M, Gangneron F. Quelle accessibilité aux ressources pastorales du Sahel? Afrique Contemporaine. 2014; $N^{\circ}$ 249:21-35.

7. Ickowicz A, Garba I, Toutain B, Cesaro J-D, Gerber P, Touré I. Plaidoyer pour un système d'information sur le pastoralisme au Sahel. Afrique Contemporaine. 2014; № 249:90-2.

8. Krätli S, Monimart M, Jalloh B, Swift J, Hesse C. Accompagner la mobilité pastorale au Tchad. Afrique Contemporaine. 2014:№ 249:69-82.

9. Metternicht G-I, Zinck J-A. Remote sensing of soil salinity: potentials and constraints. Remote Sensing Environ. 2003;85(1):1-20. https://doi.org/10. 1016/S0034-4257(02)00188-8.

10. Ministère de l'Élevage. Recensement Général de l'Élevage. N'Djamena. 2016.

11. Olivry J-C, Chouret A, Vuillaume G, Lemoalle J, Bricquet J-P. Hydrologie di Lac Tchad. Paris: ORSTOM Editions; 1996.

12. Rishmawi K, Prince S-D, Xue Y. Vegetation Responses to Climate Variability in the Northern Arid to Sub-Humid Zones of Sub-Saharan Africa. Remote Sens. 2016:8:910. https://doi.org/10.3390/rs8110910.

13. Schneider J-L. Hydrogéologie du bassin du Lac Tchad. ORSTOM; 1964.

14. Schneider J-L, Wolff J-P. Carte géologique et cartes hydrogéologiques à $1 / 1$ 500000 de la République du Tchad. Orléans: Document du BRGM N²09; 1992.

15. Sohl T-L, Sleeter B-M. Role of Remote Sensing for Land-Use and Land-Cover Change Modeling. 2012. https://doi.org/10.1201/b11964-18.

16. Valenza J. Surveillance continue de pâturages naturels sahéliens sénégalais : résultats de 1974 à 1978. Revue d'Elevage et de Médicine Vétérinaire des Pays Tropicaux. 1981;34(1):83-100.

17. Vassolo S, Seeber K, Wilczok C. Groundwater quality investigations in the Kanem and Bahr el Ghazal regions, Chad. Hannover: BGR Report; 2014.

18. Zanchetta A, Bitelli G. A combined change detection procedure to study desertification using opensource tools. Open geospatial data softw stand. 2017;2:10. https://doi.org/10.1186/s40965-017-0023-6.

19. Puissant $A$, Weber $C$. Les images à très haute résolution, une source d'information géographique en milieu urbain?. Espace géographique. 2003; 32(4):345.

\section{Publisher's Note}

Springer Nature remains neutral with regard to jurisdictional claims in published maps and institutional affiliations. 